Acta Poloniae Historica

122, 2020

PL ISSN 0001-6829

\title{
Marta Kuc-Czerep
}

https://orcid.org/0000-0003-0049-834X

Tadeusz Manteuffel Institute of History, Polish Academy of Sciences

\section{THE CONCEPT OF CITIZENSHIP IN THE POLITICAL DISCOURSE OF THE POLISH-LITHUANIAN COMMONWEALTH IN THE SECOND HALF OF THE EIGHTEENTH CENTURY}

\begin{abstract}
This article addresses some aspects of the functioning of the concept of 'citizen' in the political discourse of the Polish-Lithuanian Commonwealth in the latter half of the eighteenth century. In the dominant nobility's discourse, the concept gained a strictly defined meaning: a citizen was, namely, a person entitled to wield or exercise political power in the state. In the estate society realities, it actually boiled down to mutual identification of two concepts: 'citizen' and 'nobleman'. The bourgeois conception of citizenship took shape in confrontation with such understanding of the idea, formulated and propagated by Protestant townsmen - mainly by Wawrzyniec Mitzler de Kolof and Michał Gröll, book traders, printers and publishers from Saxony. They derived the meaning of 'citizen' from 'resident'. In such a concept, the term extended to all the inhabitants of Poland-Lithuania apart from the nobility, it included, also the townspeople and the peasantry. In this context, of relevance are the changes in the meaning of the German term Bürger (burgher, citizen of the state), which influenced Polish political discourse. This leads to the conclusion that the latter half of the eighteenth century saw the idea of citizenship in its modern meaning.
\end{abstract}

Keywords: the concept of citizenship, political discourse, eighteenth century, burghers, Warsaw

\section{I \\ INTRODUCTION}

In our day, the concept of 'citizen' [Polish: obywatel] is defined as a legal relation linking the individual with the state. Acquisition of citizenship is based on the right of land (ius soli) or the right of blood (ius sanguinis). Citizenship is associated with the acquisition of a series 
of rights, the number-one among them being participation in political life, including partaking in the exercise and controlling of state authority. ${ }^{1}$ Theoretical approaches of the idea of citizenship changed with the times. ${ }^{2}$ In light of the existing research, the eighteenth century was the key moment in the shaping of the modern conception of citizenship; this was connected to the social and economic change related to emancipative strivings of the bourgeoisie. The 'Third Estate's' strong financial position and cultural capital allowed its members to formulate political aspirations and demands to be afforded the right to participate in governing the country. ${ }^{3}$ The ideological foundation for the bourgeoisie's postulates consisted of the views proposed by the Enlightenment philosophers, particularly John Locke, Montesquieu, and Jean-Jacques Rousseau. ${ }^{4}$ In the concordant opinion of scholars, it was the French Revolution that imbued the concept of citizen with a new content. Individuals were afforded concrete legal or subjective rights, and with the status of the state's citizen, for the first time ever. ${ }^{5}$

The transformation of the subject into the citizen and the emergence of a civic society has been presented by Reinhart Koselleck, a founder of the Begriffsgeschichte school, who emphasises the association between social change and transformation of the language

${ }^{1}$ For a broader discussion, cf. Justyna Adamczyk, 'Pojęcie i znaczenie obywatelstwa', Studia Prawnicze i Administracyjne, xxv (2018), 3-9; Krzysztof Wroczyński, Obywatel, http://www.ptta.pl/pef/pdf/o/obywatel.pdf [Accessed: 25 June 2020].

${ }^{2}$ See Krzysztof Trzciński, 'Obywatelstwo w Europie. Idea i jej wyraz formalny w perspektywie historycznej', Studia Europejskie, ii (2002), 45-67; id., Obywatelstwo w Europie. Z dziejów idei i instytucji (Warszawa, 2006); Dorota PietrzykReeves, Idea społeczeństwa obywatelskiego. Wspótczesna debata i jej źródła (Toruń, 2012).

${ }^{3}$ Arguments proposed by exponents of the Third Estate have been described by Emmanuel-Joseph Sieyès in his 1789 political pamphlet Qu'est-ce que le Tiers-Etat?

${ }^{4}$ Ulrich Im Hof, Das Europa der Aufklärung (München, 1993), 179-80; Jerzy Wojtowicz, Miasto europejskie w epoce oświecenia i rewolucji francuskiej (Toruń, 2017), 4; Zdzisław Libera, Oświecenie (Warszawa, 1974), 7.

${ }^{5}$ Cf. Peter Sahlins, 'The Eighteenth-Century Citizenship Revolution in France', in Andreas Fahrmeir, Olivier Faron, and Patrick Weil (eds), Migration Control in the North Atlantic World. The Evolution of State Practices in Europe and the United States from French Revolution do the Inter-War Period (New York, 2003), 11-24; Jan Baszkiewicz, Nowy czlowiek, nowy naród, nowy świat. Mitologia i rzeczywistość Rewolucji Francuskiej (Warszawa, 1993); Krzysztof Trzciński, 'Początki nowożytnego obywatelstwa w Europie - obywatel państwa i katalog jego praw w dokumentach Rewolucji Francuskiej', Studia Europejskie, ii (2005), 67-94. 
used in political debate. ${ }^{6}$ The example he focuses on is the evolution of the concept 'citizen' (Bürger), which turned from a state-related description of a town dweller into a concept related to a citizen of the state (Staatsbürger). ${ }^{7} \mathrm{He}$ compares the experience of German-speaking countries in this respect with the socio-political situation in France and England. ${ }^{8}$ The results of his analysis inspired the subsequent scholars to follow up on his findings. ${ }^{9}$

The question about the evolvement of the idea of citizenship, understood in a modern sense, in the early modern Polish-Lithuanian Commonwealth was put forth by Stanisław Grodziski in his nowclassical book entitled Obywatelstwo w szlacheckiej Rzeczypospolitej [Citizenship in the Polish-Lithuanian Commonwealth]. ${ }^{10}$ A polemic with his findings was proposed by the reviewer Juliusz Bardach. ${ }^{11}$ The semantic scope of the concept has been analysed by several other researchers, primarily Anna Grześkowiak-Krwawicz, ${ }^{12}$ Karin Friedrich, ${ }^{13}$ and Richard Butterwick-Pawlikowski. ${ }^{14}$ 'Citizenship' ranks

${ }^{6}$ For a broader discussion, see Reinhart Koselleck (ed.), Historische Semantik und Begriffsgeschichte (Stuttgart, 1979); id., Kritik und Krise: Eine Studie zur Pathogenese der bürgerlichen Welt (München, 1959).

${ }^{7}$ Klaus Schreiner and Reinhart Koselleck, Bürgerschaft: Rezeption und Innovation der Begrifflichkeit vom Hohen Mittelalter bis ins 19. Jahrhundert (Stuttgart, 1994); Manfred Riedel, 'Bürger, Staatsbürger, Bürgertum', in Otto Brunner, Werner Conze, and Reinhart Koselleck (eds), Geschichtliche Grundbegriffe. Historisches Lexikon zur politischsozialen Sprache in Deutschland, i (Stuttgart, 1972), 672-725.

${ }^{8}$ Reinhart Koselleck, Ulrike Spree, and Willibald Steinmetz, 'Drei bürgerliche Welten? Zur vergleichenden Semantik der bürgerlichen Gesellschaft in Deutschland, England und Frankreich', in Hans-Jürgen Puhle (ed.), Bürger in der Gesellschaft der Neuzeit. Wirtschaft - Politik - Kultur (Göttingen, 1991), 14-58.

${ }^{9}$ Karin Tilmans, The Dutch Concept of the Citizen: from the Early Middle Ages till the 21st Century, https://karintilmans.nl/pdf/citizenship.pdf [Accessed: 12 Aug. 2020].

${ }^{10}$ Stanisław Grodziski, Obywatelstwo w szlacheckiej Rzeczypospolitej (Kraków, 1963).

${ }^{11}$ Juliusz Bardach, 'Czy istniało obywatelstwo w szlacheckiej Rzeczypospolitej? W związku z pracą S. Grodziskiego, Obywatelstwo w szlacheckiej Rzeczypospolitej', Czasopismo Prawno-Historyczne, xvii, 2 (1965), 263.

${ }^{12}$ See Anna Grześkowiak-Krwawicz, Dyskurs polityczny Rzeczypospolitej Obojga Narodów (Toruń, 2018), 47-50.

${ }^{13}$ Karin Friedrich, 'Obywatele i obywatelskość w wielonarodowej Rzeczypospolitej', in Anna Grześkowiak-Krwawicz and Jerzy Axer (eds), Wartości polityczne Rzeczypospolitej Obojga Narodów. Struktury aksjologiczne i granice cywilizacyjne (Warszawa, 2017), 119-50.

${ }^{14}$ Richard Butterwick-Pawlikowski, 'Chrześcijanin i obywatel w dyskursie politycznym drugiej połowy XVIII wieku’, in Grześkowiak-Krwawicz and Axer (eds), 178-9. 
among the key ideas of the political discourse in the Old Polish period, still arousing doubts as to its meaning. Hence, revisiting the issue is entirely legitimate. ${ }^{15}$

This article seeks to present the concept of citizenship as it was formulated in townspeople circles strictly associated with the Lutheran congregation in Warsaw. Scholars have hitherto focused on political treatises that shaped the noble political discourse. For this reason, one should pay attention to the views propagated by members of the Warsaw-based proto-intelligentsia of bourgeois descent, which took shape in the second half of the eighteenth century. ${ }^{16}$ The decisive importance is assignable to the booksellers and printers Wawrzyniec (Lorenz) Mitzler de Kolof ${ }^{17}$ and Michał (Michael) Gröll, who arrived from Saxony. ${ }^{18}$ Both propagated the bourgeoisie ideology, well aware of their role. ${ }^{19}$ They attracted a large group of associates, among them Tobias Bauch, ${ }^{20}$ Johann August Poser, and Johann Ferdinand Nax. ${ }^{21}$ These burghers' basic language of communication was German, and their activities combining the two linguistic areas made them transfer the ideas of German and French Enlightenment into Polish soil, remaining aware of the changes taking place in their native

${ }^{15}$ Richard Butterwick-Pawlikowski first postulated that statistical methods be employed in the research on the idea of 'citizen': id., 'Chrześcijanin i obywatel', 178-9; Kornelia Kończal, 'Czego możemy się nauczyć od Reinharta Kosellecka, czyli o potrzebie badania polskiej semantyki historycznej. Rozmowa z Profesorem Maciejem Janowskim', Stan Rzeczy, x (2016), 87-8.

${ }^{16}$ For a broader review of the topic, see Maciej Janowski, Narodziny inteligencji 1750-1831 (Warszawa, 2008).

${ }^{17}$ Elżbieta Aleksandrowska, Wawrzyniec Mitzler de Kolof (1711-1778), in Teresa Kostkiewiczowa and Zbigniew Goliński (eds), Pisarze polskiego oświecenia, i ( Warszawa, 1992), 167-86.

${ }^{18}$ Adolf Pawiński, Michat Gröll: obrazek na tle epoki stanistawowskiej (Kraków, 1896).

${ }^{19}$ Mieczysław Klimowicz and Roman Kaleta, Prekursorzy Oświecenia: Monitor z roku 1763 - na tle swoich czasów; Mitzler de Kolof - redaktor i wydawca (Wrocław, 1953).

${ }^{20}$ Jerzy Dygdała, “"Toruńczanin” Tobias Bauch - redaktor warszawskiego Patryoty Polskiego z 1761 r.', Wiek Oświecenia, xix (2003), 109-24. Basing on the extant municipal records, the author established that the editor's Christian name was Tobias and not Teodor; id., 'Toruński inteligent z XVIII wieku (nauczyciel, ochmistrz dworu, guwerner, dziennikarz, pisarz miejski, rajca, pastor) w poszukiwaniu zatrudnienia. Przypadków Tobiasa Baucha (1733-1795), redaktora "Patryoty Polskiego" ciąg dalszy', Wiek Oświecenia, xxxiii (2017), 189-206.

${ }^{21}$ Edmund Rabowicz, 'Jan Ferdynand Nax', in Polski stownik biograficzny (hereinafter: PSB), xxii (Wrocław-Warszawa-Kraków-Gdańsk, 1977), 637-40. 
tongue. The question of Polish-German conceptual transfers is worth considering; to be more specific, the degree to which the semantic evolution of the German concept of Bürger influenced the understanding of the meaning of the Polish obywatel should be explored.

The focus on the second half of the eighteenth century stems from the view, well-established among Polish scholars, that the period between the late 1770s and the end of the Old Polish age was of particular importance to the formation of the language of political discourse in the Commonwealth. ${ }^{22}$ The source base behind the analysis has been the periodicals published in Warsaw in the century's latter half. The press was an essential public opinion-forming instrument, and means of dissemination of the Enlightenment ideals. Moreover, it provided the forum for the unprivileged social strata. ${ }^{23}$ Burgher treatises and memorials from the time of the dispute between the nobility and the bourgeoisie in the Lutheran milieu, as well as from the years of the townsfolk estate's struggle for their rights during the Four Years' Sejm of 1788-92, have also been used. Interestingly, many of these prints came out in German, or in a bilingual Polish-German version.

II

THE CONCEPT OF ‘CITIZEN’ IN THE NOBILITY'S POLITICAL DISCOURSE

Based on the research done to date, the term 'citizen' appeared quite early in Polish political discourse. In the second half of the sixteenth century, both the Latin and Polish language versions (civis/cives and obywatel, respectively) was used by authors of political treatises published at the time. ${ }^{24}$ It was a period of high importance for the shaping of the principles of the Commonwealth's socio-political system. The language of political debate was getting shaped at the time, essentially influenced by the ancient tradition. It was in reference

${ }^{22}$ Cf. Anna Grześkowiak-Krwawicz, 'Czy historyk powinien interesować się językiem?’, in Aleksandra Antoniewicz, Rozalia Kosińska, and Piotr Skowroński (eds), Zmierzch $i$ świt. Stanisław August i Rzeczpospolita 1764-1795 (Warszawa, 2015), 31-40.

${ }^{23}$ Stanisław Salmonowicz, 'Die Zeitschriftentypen in Polen und ihre Rolle als Förderer der Aufklärung', in Hans Lemberg (ed.), Zeitschriften und Zeitungen des 18. und 19. Jahrhunderts in Mittel- und Osteuropa (Berlin, 1986), 65.

${ }^{24}$ Grześkowiak-Krwawicz, Dyskurs polityczny, 49. 
to it that the scope of understanding of ideas such as republic [rzeczpospolita], liberty, virtue, and citizen was formulated. ${ }^{25}$

Stanisław Grodziski presented the period's two conflicting conceptions. On the one hand, there were Andrzej Frycz Modrzewski, Andrzej Wolan, and Sebastian Petrycy, who postulated that the Commonwealth be perceived as a political community based on one legal system, in respect of which all the residents were meant to remain equal - and it was in this sense that they were regarded as citizens of Polish-Lithuanian res publica. ${ }^{26}$ On the other hand, there were opinions that only the one who actively participated in political life could be considered as a citizen. Stanisław Orzechowski expressed his opinion in this spirit: "The Commonwealth is an assembly of the citizens, connected by the commonness of the law and the company of benefit". ${ }^{27}$ Among the country's citizens, he included the king, the knighthood and the clergy, while the townspeople and peasants were outside the 'civic community'. ${ }^{28}$ This meant that the country's inhabitants were categorised into citizens and the other population, the former consisting of those who had obtained education and had time to deal with the matters of the res publica, and those who focused on more mundane professions. ${ }^{29}$ This view was generally accepted by the nobility educated in line with classic ideas. ${ }^{30}$

Since the middle of the sixteenth century, citizenship was understood in the Commonwealth's political discourse as the right to participate in the life of a political community actively. According to this conception, citizenship was associated with a defined set of freedoms and privileges which gave access to state offices and dignities and the right to actively participate in the activities of the diet [sejm]

${ }^{25}$ Anna Grześkowiak-Krwawicz, “"Nowe wino w starych butelkach”. O języku politycznym Stanisława Konarskiego', Wiek Oświecenia, xxxii (2016), 12.

${ }^{26}$ For a broader review of the topic, cf. Grodziski, Obywatelstwo, 44-5, Marek Simlat, 'Teoria polityczna Andrzeja Frycza Modrzewskiego. Próba rekonstrukcji', Państwo i Spoleczeństwo, iii (2003), 99-109.

${ }^{27}$ Stanisław Orzechowski, Rozmowa albo Dyalog okoto egzekucyjej Polskiej Korony (Kraków, 1919), 11.

${ }^{28}$ Przemysław Krzywoszyński, Stanisław Orzechowski-ideolog demokracji szlacheckiej (Poznań, 2010), 28-9.

${ }^{29}$ Grodziski, Obywatelstwo, 48.

${ }^{30}$ Karin Friedrich quotes the opinion of Wacław Goślicki, who opposed the granting of civil rights to those who were not noble, educated, or honest, but were "destined to bondage and allegiance”; see Friedrich, 'Obywatel i obywatelskość, 134. 
and dietines [sejmiki]. ${ }^{31}$ The strengthening of the noble estate's legal position caused that 'citizen' became synonymous to 'nobleman' [szlachcic]. ${ }^{32}$ With the weakening of the Reformation movement, Poland-Lithuania saw the further limitation of the meaning of the concept. In the heat of the political battle, Catholic authors, primarily the Rev. Piotr Skarga, argued that only a Catholic could well serve the Commonwealth and be a rightful citizen. ${ }^{33}$ In the latter half of the seventeenth century, the conviction became dominant that only a Catholic noble person could be a Poland-Lithuania's citizen. ${ }^{34}$ Consequently, dissidents were pushed out to the margin of the polity; later on, they were deprived of the possibility to enjoy the rights and prerogatives of the nobility.

Identification of the concepts 'citizen' and 'nobleman' was maintained in the Commonwealth's political discourse throughout the seventeenth and, almost, throughout the eighteenth centuries. ${ }^{35}$ The semantic scope of the concept dominant in the public space was pointed to in the writings of eighteenth lawyers. According to Gottfried Lengnich, "yet, in our law, only the nobility is named a citizen, in particular, and it solely has a share in the affairs of the Commonwealth". ${ }^{36}$ Wincenty Skrzetuski made quite a similar point: "Those [i.e. the 'nobility called landowners'] are also understood by our Laws as being Citizens, to the extent that whatever is said of Civic rights, freedoms, or liberties, it strictly belongs to the Nobility themselves, be it in the Senatorial or Knightly estate, in the Secular or Clerical

${ }^{31}$ Cf. Adam Lityński, 'Samorząd szlachecki w Polsce XVII-XVIII wieku', Kwartalnik Historyczny, xcix, 4 (1992), 17-34.

${ }^{32}$ Cf. Anna Grześkowiak-Krwawicz, 'Rzeczpospolita - pojęcie i idea w dyskursie politycznym Rzeczypospolitej Obojga Narodów. Rekonesans', Odrodzenie i Reformacja w Polsce, lvi (2012), 20-1.

${ }^{33}$ Piotr Skarga, 'Przestroga do Katolików o zachowaniu z Heretyki', in Mirosław Korolko, Klejnot swobodnego sumienia: Polemika wokót konfederacji warszawskiej w latach 1573-1658 (Warszawa, 1974), 106; Urszula Augustyniak, 'Wpływ konfesjonalizacji katolickiej na dyskurs polityczny w Rzeczypospolitej XVI-XVIII wieku. Wizje państwa i społeczeństwa', in Grześkowiak-Krwawicz and Axer (eds), 84-5.

${ }^{34}$ Karin Friedrich points to this issue, remarking that Catholic authors (Augustyn Rotundus, Piotr Skarga) regarded concord among the citizens as the foundation of the Commonwealth; they believed that confessional unity was necessary to sustain it; see Friedrich, 'Obywatele i obywatelskość', 122-4.

${ }^{35}$ Grześkowiak-Krwawicz, Dyskurs polityczny, 47.

${ }^{36}$ Gotfryd Lengnich, Prawo pospolite Królestwa Polskiego, ii (Kraków, 1836), 206. 
one, whatever the case might be". ${ }^{37}$ A similar communication came from another lawyer, Teodor Ostrowski. ${ }^{38}$ In Stanisław Grodziski's opinion, the awareness shared by the noblemen discerned between citizens (those holding political rights, i.e. noble landholders) and the subjects (unprivileged estates, burghers, and peasants). ${ }^{39}$

The second half of the eighteenth century saw the appearance of postulates related to the improvement of the legal and political situation of the bourgeoisie. Józef Wybicki was one of those speaking in favour of such a solution. ${ }^{40}$ As Jerzy Michalski remarks, analysis of the municipal reform projects proposed at that time indicates, however, that the nobility intended to afford very restricted rights to municipal representatives, retaining the right to decide on the state's affairs as its sole privilege. ${ }^{41}$ Józef Kazimierz Kossakowski, the author of a 1788 political treatise, significantly entitled Obywatel, shared these views. ${ }^{42}$ Under the guise of referring to the ancestors' tradition (and neglecting foreign novelties), the author proposed to introduce substantial changes to the political system, in respect of the procedure of dietine deliberations. He was sure, however, that a genuine citizen of the Commonwealth was a settled-down nobleman; as he specified, "all the other inhabitants in our country, who carry the whole of their property in their pockets, on promissory notes and charters, I rightly consider as arrivals and foreigners, not in the least sensitive to the country's beatitude". ${ }^{43}$ In his opinion, only the hereditary land, that is, the fatherland or patrimony [ojczyzna/ojcowizna], was the basis for obtaining the status of citizen. ${ }^{44}$

37 Wincenty Skrzetuski, Prawo Polityczne Narodu Polskiego (Warszawa, 1782), 187.

38 Teodor Ostrowski, Prawo Cywilne albo szczególne Narodu polskiego z Statutów $i$ Konstytucyi koronnych i litewskich zebrane rezolucyami Rady Nieustaiacej obiaśnione $z$ dodatkami z praw kanonicznego, magdeburskiego, chetmińskiego pomnożone i porządkiem praw rzymskich (Warszawa, 1784.)

${ }^{39}$ Grodziski, Obywatelstwo, 166.

40 Władysław Konopczyński, Polscy pisarze polityczni XVIII wieku (Kraków, 2012), 210-11.

${ }^{41}$ Jerzy Michalski, 'Sprawa miejska w opinii szlacheckiej przed Sejmem Czteroletnim’, Przegląd Historyczny, xlii (1951), 303.

42 Józef Kazimierz Kossakowski, Obywatel (Warszawa, 1788).

43 Ibid., 11.

${ }^{44}$ As Józef Kazimierz Kossakowski argued, "My land, my Fatherland, the title and the substance of my citizenship in a free country were more pleasing to the Poles-of-yore than the urban delicacies, vain entertainments, splendid attires, 
In the opinion of Grodziski, much more progressive views were advocated by Stanisław Staszic, Hugo Kołłątaj, and Jacek Jezierski. In contrast to Grodziski, they did not opt for the conception of common citizenship. While using the concept 'citizen', Staszic would not extend it to all the residents of Poland-Lithuania; he used the concept 'nation' instead, seeing it as composed of all the four social estates. ${ }^{45}$ Yet, he clearly pointed out to the need to rebuild the Commonwealth's social structure, referring to this end to the Enlightenment ideals. ${ }^{46}$ Both Staszic and Kołłątaj evoked the ideal of social usefulness of individuals and commended the virtue of assiduity. For this reason, they believed that being born to a noble family was not a satisfactory premise for holding offices and enjoying citizen privileges. ${ }^{47}$

Both of these authors unambiguously identified the civil rights (including one's personal property, ownership of movables and land), which should be vested in all the country's inhabitants, as opposed to

which, by destroying a particle of the country, destroy the most noble taste in every well-thinking Citizen", ibid., 12-13.

${ }^{45}$ Stanisław Staszic so reminded the noblemen: "The most-worthy Rank of Nobility! You cannot say otherwise than admit that you do not embrace [all] the Poles, but just one particle; that you are not the entire Polish Nation but only an estate within it: the defensive estate, the one of knighthood". Let us add that the term 'nation' [naród] referred since the sixteenth century to the nobility, and functioned as 'the noble estate'; Stanisław Staszic, Przestrogi dla Polski, ed. by Stefan Czarnowski (Wrocław, 2008), 5. For a broader discussion of the concept of nation in Staszic's writings, see Andrzej Walicki, 'Idea narodu w polskiej myśli oświeceniowej’, Archiwum Historii Filozofii i Myśli Spotecznej, xxvi (1980), 61-2.

${ }^{46}$ Staszic's assessment of the situation existing in Poland-Lithuania was quite clear: "Of the seven million Poles, scarcely a hundred thousand enters the society and has the right of citizenship. Of the nine thousands of square miles, scarcely several hundred square miles may have their proprietors. Apart from the nobility, no other Pole is allowed to be a citizen, or proprietor"; Staszic, Przestrogi, 146.

${ }^{47}$ Hugo Kołłątaj postulated as follows: "The Commonwealth cannot consist of indolent, lazy people who have lost the habit of working; it cannot be formed of evil people with corruptible souls and hearts filled with esurience, breathing with avenge, and scorning equality; of such who are attached more to their birth and property than the obligations of the Office; and, lastly, of people who mark an overly large difference between the Estates amidst the inevitably necessary Professions.”; Hugo Kołłątaj, Do Stanisława Małachowskiego ... anonyma listów kilka: Częśc III o poprawie Rzeczypospolitey ... od dnia 11 listop. do dnia 19 grudnia roku 1788 (Warszawa, [1789]), 21. Staszic emphasised that "In a company, every idler is a certain sign that a citizen is suffering a harm"; Staszic, Przestrogi, 113-14. 
political rights (in respect of legislative power), which only citizens could enjoy. ${ }^{48}$ The reforms proposed by Staszic and Kołłątaj were limited to granting to burghers the right to hold civil and military offices. In contrast, representatives of towns would become members of the parliament (Sejm), without infringing the existing position of the nobility. ${ }^{49}$ The difference between their conceptions was that Kołłątaj proposed a further-fetched solution in that a separate municipal house would be set up within the parliament. ${ }^{50}$ The proposition would consist in including burghers among the Commonwealth's citizens (not fully equal in rights, though)..$^{51}$

In the 1790s, Franciszek Salezy Jezierski joined those who referred to the concepts of 'nation' and 'citizen'. According to this author, the nation is an assembly of people sharing a language, customs, mores and morals, who are united under one legislation, which extends to all the citizens. Nation and Government, remarked he, are two separate issues. ${ }^{52}$ Jezierski provided a definition of citizenship in an encyclopaedia he compiled. According to it, all the country's inhabitants were citizens, naturally divided into the estates of commonalty (burghers and peasants) and nobility; only the latter formed a political rank or estate. ${ }^{53}$ The commonalty, called in France 'the third estate', preserved the national language and customs, as opposed to the cosmopolitan nobles. ${ }^{54}$ Jezierski remarked that the Commonwealth was a good of all the citizens, whilst the laws and privileges in force made the country a nobility-based Commonwealth. ${ }^{55}$

${ }^{48}$ In Staszic's view, "Political rights are associations between the officials and the citizens, and between the citizens and the officials", ibid.

${ }^{49}$ Staszic, Przestrogi, 53.

${ }^{50}$ Kołłątaj, Do Stanisława Małachowskiego, 7.

${ }^{51}$ Jerzy Michalski, 'Z problematyki republikańskiego nurtu w polskiej reformatorskiej myśli politycznej w XVIII wieku', Kwartalnik Historyczny, xc, 2 (1983), 329, 335-6.

${ }^{52}$ See 'Naród' in Franciszek Salezy Jezierski, Niektóre wyrazy porządkiem abecadta zebrane (Warszawa, 1791), 135-8.

53 'Obywatelstwo', ibid., 151-2.

54 'Pospólstwo', ibid., 176.

55 'Rzeczpospolita', ibid., 190. 


\section{III}

\section{THE DICTIONARY DEFINITION OF THE CONCEPT OF 'CITIZEN'}

Since texts written in German functioned in Polish political discourse, the rendering of the Polish term obywatel into German, and the semantic scope afforded to the German notion Bürger, are of particular importance. Among the few Polish-German dictionaries compiled in the eighteenth century, ${ }^{56}$ worthy of attention are the lexicographical works by Michał Abraham Trotz, instructor of the Polish language at the university of Leipzig (in 1750-69) and, for many years, associate of the Załuski brothers, initiators of scientific and cultural life in Warsaw under the Wettin kings. ${ }^{57}$ He was associated through his family with the Warsaw Lutheran congregation; ${ }^{58}$ hence the book trader Michał Gröll's significant involvement in the dissemination of Trotz's publications in the area of Warsaw. ${ }^{59}$

Trotz tends to be shown as a representative of the new, Enlightenment cultural formation, a man who manifested his vivid interest in research into the Polish language. ${ }^{60}$ His main work is a four-volume dictionary whose first volume was a two-segment French-German-Polish part (1744-7); volume three was a Polish-French-German part (1764). The last, German-Polish, part came out in 1772, edited by Stanisław Moszczeński, Trotz's successor in the teaching work. ${ }^{61}$

In the forming of his technique as a lexicographer, Trotz referred to foreign models, mainly the German researchers, whilst also using

${ }^{56}$ See Piotr Grzegorczyk, Index lexicorum Poloniae. Bibliografia słowników polskich (Warszawa, 1967).

${ }^{57}$ Aleksandra Iwanowska, 'Michał Abraham Troc i bracia Załuscy', Kwartalnik Historii Nauki i Techniki, xxxiv, 2 (1989), 237-60.

${ }^{58}$ His grandfather Michał Trotz was a merchant and a member of the board of the Warsaw Lutheran congregation; see Wojciech Kriegseisen, 'Początki, czyli ewangelicy warszawscy w XVII i XVIII wieku', in Juliusz Gardawski and Anna Wołodko (eds), Ewangelicy $w$ dziejach Warszawy. Materiaty $z$ sesji naukowej w Bibliotece Uniwersyteckiej w Warszawie, 13 czerwca 2008 (Warszawa, 2008), 12.

59 The books by Michał Abraham Trotz were available also from other Warsawbased booksellers, incl. Mitzler de Kolof and Jan August Poser; see Aleksandra Iwanowska, 'Michał Abraham Troc w kulturze naukowej lat czterdziestych XVIII wieku', Kwartalnik Historii Nauki i Techniki, xxxviii, 3 (1993), 59.

${ }^{60}$ Iwanowska, 'Michał Abraham Troc', 36-7.

61 The volume's subsequent editions were published in Leipzig in 1791, 1800, and 1807; all the four volumes were published in Leipzig in 1812; ibid., 47. 
earlier works by Polish authors. ${ }^{62}$ This immersion in both languages was of importance as regards his sensitivity to the changes in sociopolitical ideas in both German and Polish, which is observable with the semantics of the terms mieszczanin - obywatel-Bürger. Among the entries in volume one of the dictionary, one finds the French citoyen, which is rendered as 'Bourgeois, Bürger, Mieszczanin'. ${ }^{63}$ In Trotz's Nowy Dykcyonarz to jest Mownik polsko-niemiecko-francuski [New Lexicon, or a Polish-German-French Dictionary], published in 1764, the term mieszczanin is translated as Bürger, bourgeois, whereas mieszczanie is die Bürgerschaft, bourgeoisie. ${ }^{64}$ The term obywatel has the following equivalents: Insaß, Einwohner, habitat; it was thus emphasised that citizenship was related to inhabiting a specified territory. As an example of the use of this word, the phrase "citizens of this town, country" is given. Related to it is the rendering of the term obywatelstwo as "Insaßschaft, alle Einwohner eines Landes, Bürger-Recht". ${ }^{65}$ In this meaning, the term obywatel was interpreted by Grzegorz Knapiusz, one of the major Polish lexicographers. ${ }^{66}$ In a 1643 dictionary, he described the term obywatel in terms of 'inhabitant', as opposed to 'arrival' or 'foreigner' ${ }^{67}$

One should pay attention to the fourth volume of Trotz's dictionary, first published in 1772, where the term Bürger is rendered dually: as a burgher, person admitted to the municipal law; and, as "citizen, of a country, land, or county [powiat]; in this meaning, nobleman, and burgher, and peasant is understood". ${ }^{68}$ It is significant that such a definition appeared in the 1770s; it probably

62 Ibid., 50-3.

${ }^{63}$ Michał Abraham Trotz, Nouveau dictionnaire françois, allemand et polonais (Leipzig, 1744), 1194.

${ }^{64}$ Michał Abraham Trotz, Nowy dykcyonarz to iest Mownik polsko-niemiecko-francuski (Leipzig, 1764), 828.

65 Ibid., 1128.

${ }^{66}$ For a broader discussion, cf. Jadwiga Puzynina, "Thesaurus” Grzegorza Knapiusza: siedemnastowieczny warsztat pracy nad jezykiem polskim (Wrocław, 1961).

67 'Obywatel, mieszkaniec, incola, habitator', in Grzegorz Knapiusz, Thesavrvs polonolatinograecvs sev promptvarivm lingvae latinae et graecae Polonorum in tres tomos diuisum Polonorum, Roxolanorum, Sclauonum, Boëmorum vsui accommodatum [...], i (Kraków, 1643), 584.

${ }^{68}$ Michał Abraham Trotz, Vollständiges Deutsches und Polnisches Wörter-Buch: welches die gebräuchlichsten Wörter und Redens-Arten, auch vornehmsten Kunst und Handwerks-Wörter enthält, als M. A. Trotzens, Polnischen Wörter-Buches letzter Theil / herausgegeben durch Stanislaus Nałęcz Moszczenski (Leipzig, 1772), 291. 
influenced the stances of bourgeoisie editors and authors of polemical texts. The semantic duality of Bürger, as burgher and citizen, was confirmed in the dictionaries compiled in the late eighteenth and early nineteenth centuries, including the one by Karol Winkler. ${ }^{69}$ Samuel Bogumił Linde, who intensively used the books published by Trotz, included two meanings in his dictionary's entry Obywatel: an inhabitant of the country and a person "sharing the state's civil and political liberty". ${ }^{70}$

IV

\section{THE BOURGEOIS CONCEPT OF CITIZENSHIP}

The periodicals published in Warsaw since the middle of the eighteenth century were the main channel of transmission of bourgeoisie ideals. ${ }^{71}$ Articles published in the Monitor, which was regarded as the major ethical and customs-related periodical of the Polish Enlightenment, deserve special attention. Monitor was set up on the initiative of Ignacy Krasicki and Adam Kazimierz Czartoryski, and was financially supported by King Stanislaus Augustus. Its first editors were Franciszek Bohomolec and subsequently Józef Minasowicz. ${ }^{72}$ In 1773-8, Wawrzyniec Mitzler de Kolof became the editor, and heavily influenced the periodical's ideological programme. Elżbieta Aleksandrowska sees the Monitor as the period's "tribune of intellectual and bourgeois enlightenment". ${ }^{73}$ Let us remind that it was not the first publishing initiative of the learned Saxon. In the Warsaw circle, he came off as

${ }^{69}$ The term Bürger was rendered as mieszczanin, obywatel [i.e. burgher, citizen]; the adjective bürgerlich being obywatelski, cywilny, miejski [civic, civil, urban, or 'of the townsfolk']; the noun Bürgerstand stood fort the rank (estate) of townspeople; Karol Winkler, Nowy polsko-niemiecki dykcyonarz (Lublin, 1801).

${ }^{70}$ Samuel Bogumił Linde, Stownik jezyka polskiego, ii, Part 1 (Warszawa, 1809), 400.

${ }^{71}$ Salmonowicz, 'Die Zeitschriftentypen in Polen', 65.

${ }^{72}$ See Elżbieta Aleksandrowska, 'Jeszcze "wśród redaktorów i autorów «Monitora»": glosa do publikacji Tadeusza Frączyka: $z$ warsztatu bibliografa "Monitora"', Pamiętnik Literacki: czasopismo kwartalne poświęcone historii $i$ krytyce literatury polskiej, lxxi, 2 (1980), 189-217; Barbara Wolska, “Monitor": 1765-1785. Wybór, opracowała i wstępem poprzedziła E. Aleksandrowska, Wrocław-Warszawa-Kraków-Gdańsk 1976' [a review], Pamiętnik Literacki: czasopismo kwartalne poświęcone historii i krytyce literatury polskiej, lxxi (1980), 349-61.

73 "Monitor" 1765-1785. Wybór, ed. by Elżbieta Aleksandrowska (WrocławWarszawa-Kraków-Gdańsk, 1976), lxiii. 
a publicist with strong social and political views. ${ }^{74}$ The other editors and publishers of moral and customs-related periodicals were Tobias Bauch $^{75}$ and Johann August Poser. ${ }^{76}$

In press articles, the burghers referred to a specific set of political and social concepts which had been present in Poland-Lithuania's political discourse since the sixteenth century. However, these authors gave them a different, more profound sense, which was distant from the dominant ideology of the nobility. For them, the point of reference was the ideas advocated by Enlightenment philosophers; their knowledge of the postulates proposed by the German and French bourgeoisies was no doubt of importance. ${ }^{77}$

An analysis of the press discourse clearly demonstrates that the bourgeois editors much less frequently referred to the concept 'Commonwealth' [Rzeczpospolita], which in the second half of the eighteenth century still denoted a political community or polity encompassing free citizens (nobility). ${ }^{78}$ They propagated a different conception of organising the state structures, according to which the state authority ought to be separated from the civic community; hence, they would prefer using terms such as 'government', 'country', 'state' , 'Poland'. ${ }^{79}$

${ }^{74}$ Aleksandrowska, 'Wawrzyniec Mitzler de Kolof', 172-3.

${ }^{75}$ In 1761, in association with Mitzler de Kolof, he published the periodical Patryota Polski, Kartki Tygodniowe Zawierajacy.

${ }^{76}$ Poser was the publisher of the periodical Zbior Roznego Rodzaju Wiadomosci z Nauk Wyzwolonych, Filozofij, Prawa Przyrodzonego, Historyi, Polityki, Moralney, Tudziez Jnnych Umieiętnosci y Rozmaitych Uwag do Pozytku y Zabawy Publiczney Stużacy, i-iv (Warszawa, 1770).

${ }^{77}$ The printed bookseller catalogues demonstrate that the bookstores they ran offered books by the major authors of German and French Enlightenment, including Christian Wolff, Johann Christoph Gottsched, as well as Voltaire, Montesquieu, Rousseau, and Mably. For a broader review of the topic, see Michał Cieśla, 'Drei ausländische warschauer Buchdrucker und Verleger des 18. Jahrhunderts als Mittler Aufklärerischen Ideengutes in Polen', in Herbert Georg Göpfert, Gerard Koziełek, and Reinhart Wittmann (eds), Beiräge zur Geschichte der Kommunikation in Mittel- und Osteuropa (Berlin, 1977), 143.

${ }^{78}$ Stanisław Konarski used this traditional understanding of rzeczpospolita as a community of noble citizens as late as mid-eighteenth century; see Anna Grześkowiak-Krwawicz, 'Rzeczpospolita - pojęcie i idea w dyskursie politycznym Rzeczypospolitej Obojga Narodów. Rekonesans', Odrodzenie i Reformacja w Polsce, lvi (2012), 6-35; ead., "Nowe wino"', 14.

${ }^{79}$ The research conducted by Ewa Bem-Wiśniewska has shown that since the 1770s the word Rzeczpospolita appeared in the records much less frequently. 
The concept most frequently used in this context was 'Fatherland' or 'homeland' [Ojczyzna; das Vaterland]. This supra-estate word enabled to build a particular emotional bond between the country and its inhabitants. ${ }^{80}$ Love for the fatherland was, in terms of the bourgeois ethical code, the major virtue of a human being (patriot, citizen). It signified the readiness for devoting one's property and life in his home country's defence, in a situation of its endangered existence; in everyday life, it would demand that one's private good not be preferred at the expense of the interest of the home country. ${ }^{81}$ This was associated with the dissemination of the term 'patriot'; significantly, the word was used in the title of a periodical edited by Tobias Bauch. ${ }^{82}$

The way the townsmen perceived the purpose behind a polity was specific, as attested by their multiple uses of the term 'universal felicity' ${ }^{83}$ It was rooted in their conviction that man's good and personal happiness was dependent upon the blessedness and successfulness

In Anna Grześkowiak-Krwawicz's opinion, this has to do with the endeavours to make the political language more precise, which was reflected in a clear differentiation between the concepts of 'government', 'nation', 'fatherland/homeland', 'country', and 'society' [towarzystwo; the more modern term being spoteczeństwo], which in diverse contexts replaced the idea of Rzeczpospolita. For a broader discussion, see Ewa Bem-Wiśniewska, 'Wizja Rzeczypospolitej w epoce staropolskiej. Od historii języka do historii kultury', in Bogusław Dybaś, Paweł Hanczewski, and Tomasz Kempa (eds), Rzeczpospolita w XVI-XVIII wieku. Państwo czy wspólnota? (Toruń, 2007); Grześkowiak-Krwawicz, Dyskurs polityczny, 63.

${ }^{80}$ The concept of ojczyzna evolved from its sixteenth-century meaning as 'patrimony' - the land inherited from the ancestors, to the modern understanding in terms of a country's territory; see Ewa Bem, "Termin "ojczyzna” w literaturze XVI i XVII wieku. Refleksje o języku', Odrodzenie i Reformacja w Polsce, xxxv (1989), 131-56.

${ }^{81}$ Wawrzyniec Mitzler de Kolof mentioned love for the home country (Fatherland) as the major virtue in a code of ethics included in Letter 4 of this treatise on the theatre. He defined patriotism thus: "Dass die Liebe zu seinem Vaterlande die grösste Tugend eines rechtschaften Einwohners ist"; cf. Mitzler de Kolof, Brief eines Gelehrten aus Wilna an einen bekannten Schriftsteller in Warschau die polnischen Schaubühnen betreffend: [Briefe 1-5] (Warschau, 1776), 93.

${ }^{82}$ The idea of love for the home country (homeland) was an important element in Poland-Lithuania's political discourse; Anna Grześkowiak-Krwawicz remarks that it was inseparably connected to the idea of citizenship, and points to the fact that in his dictionary of the Polish language, Samuel Bogumil Linde explains the term 'patriotism' [patriotyzm] with one word, that is, citizenship [obywatelstwo]. See Grześkowiak-Krwawicz, Dyskurs polityczny, 304.

${ }^{83}$ Monitor 1773, no. 56, 467; Patryota Polski, Kartki Tygodniowe Zawierajacy (5 May 1761), 6, 41 . 
of the society as a whole. ${ }^{84}$ Associated with it was a different understanding of freedom, or liberty, which the burgher authors referred to the entire state rather than one privileged estate-of-the-realm. ${ }^{85}$ The editors promoted in their periodicals a defined set of virtues, among them industriousness, saving, temperance or restraint, and reliability or diligence. ${ }^{86}$ Evaluation of the concrete individual from the standpoint of his usefulness to the entire community became essential. ${ }^{87}$ In consequence, the burghers called into question the sense of further functioning of a social order founded upon the 'blood and birth' status; instead, they postulated a social system based on the criterion of one's skills and education.

This bourgeois vision of the organisation of the state institutions and social relations directly implied a reinterpretation of the concept of 'citizen' Wawrzyniec Mitzler de Kolof published its full definition in a 1773 issue of Monitor, the periodical he edited. As we are told, "each of these is a Citizen who was born in our country, dwells therein, derives benefits from it, and remains together with use under the same laws; and, that there is not the slightest or the most abject man, let alone an assembly entire, that would be free of the obligation to serve the Fatherland, so overwhelming and substantial as it is". ${ }^{88}$ This definition clearly referred to comprehending the concept of 'citizen' as an inhabitant of the state (the German for 'citizen' being Einwohner). In this sense, not only a nobleman but also a burgher and a peasant would be a citizen of the Commonwealth. What is more, there is an identifiable conviction that none of the citizens might be released or

${ }^{84}$ The motif of prevalence of the good of a community over the good of individuals, appearing in the treatises by Stanisław Konarski and Stanisław Staszic, was absent in the traditional nobility's discourse; cf. Grześkowiak-Krwawicz, "Nowe wino"', 22.

${ }^{85}$ Apart from the freedom (liberty) of its citizens, of importance in Konarski's discourse is the freedom of the Commonwealth - its independencja, understood as the country's independence; ibid., 20.

${ }^{86}$ The idea of virtue [ cnota] was an essential element of the political discourse in sixteenth-century Commonwealth. The virtues a nobleman-citizen was expected to boast included love for the home country and 'common weal', fortitude, prudence, justice, and moderation. The discussion on civic virtues was resumed in the second half of the eighteenth century. For a broader review of the topic, see Grześkowiak-Krwawicz, Dyskurs polityczny, 257-8, 285.

87 Zbiór Roznego Rodzaju Wiadomości, iii, 25, 40.

${ }^{88}$ Monitor, 7 (1773), 55. 
removed from the duty to serve his home country. This translates into the postulate (not directly expressed) that every citizen of the country, regardless of his social-estate background, ought to be provided with the possibility to hold offices and make laws. In the editor's opinion, continued maintenance of the nobility's privileged status did not serve well the state's development. He emphasised that the position of a concrete person should not depend on the criterion of birth but rather, on the individual's skills and education; appointment of a candidate to an office should primarily be based on his knowledge and competencies. ${ }^{89}$

The burgher editors attached high importance to the question of education (being one of the most essential postulates of the Enlightenment authors); the issue was addressed by Mitzler de Kolof who, again in the Monitor, postulated that a standard education system should be introduced in the country. The new school initiatives of the time, such as the Piarist Collegium Nobilium or the Corps of Cadets, were intended for the noble-born youth. The editor demanded that support be provided to the schools at which children born into burgher families and of 'simple commons' background could be taught. Extending a state education system on these children would contribute to turning them into "good citizens, of use to their home country". ${ }^{90}$

His views were coincident with the opinions expressed by the Piarist monk Adolf B. Kamieński, whose treatise on education was published by Michał Gröll in 1774. ${ }^{91}$ This author argued that the education system ought to extend to all the residents of the state, ${ }^{92}$ since - regardless of their estate affiliation - they were citizens (fellow-countrymen)

${ }^{89}$ Monitor, 57 (1773), 474.

${ }^{90}$ Ibid., 476.

${ }^{91}$ Adolf Bartłomiej Kamieński, Edukacya obywatelska (Warszawa, 1774). It was one of the numerous Piarist publications on education; this production was related to the ongoing reform of Piarist school system. Let us note that since the 1770s, education was described as 'civic' [obywatelska]. For a broader discussion, see Piotr Badyna, Model czlowieka w polskim piśmiennictwie parenetycznym XVIII w. (do 1773 r.) (Warszawa, 2004); Irena Stasiewicz-Jasiukowa, Człowiek i obywatel w piśmiennictwie naukowym i podręcznikach polskiego Oświecenia (Wrocław, 1979).

92 The project's basic purpose was as follows: "When I refer to a Civic Education, what I am willing to understand by it is introduction of sciences of benefit to the country for citizens of all the conditions, and establishment in diverse places of the schools necessary for the purpose and casting the same with teachers, so that the light of skills might be shared among the entire nation, and the latter 
within it. Education would be meant to build a tie between the fellow citizens and attachment to the shared homeland: “... whilst, being born in a state of citizenship, every Citizen owes gratitude, right after God and his Parents, to his Homeland, and the latter ought, in particular, to exercise endeavour around the upbringing of their citizens, and so the education, through which we are to become sons of our Homeland, belongs to it and is its quite-particular duty indeed". ${ }^{93}$ The intended purpose behind the education was to instil civic virtues in the pupils, and that is, serenity, love for fellow-countrymen, justice, temperance, obedience to the laws and superiors. Kamieński imposed on the government the concrete obligation to provide appropriate educational opportunities to every citizen. His use of the concept of citizen not only in reference to noblemen but also to townsfolk and peasants did not mean to suggest that concrete political rights were assigned to the latter two groups, though. ${ }^{94}$

In the political discourse of the second half of the eighteenth century, the opinion expressed by the leading political authors, whereby only a Christian could be a good citizen, prevailed. ${ }^{95}$ This dependence, which was linked to the condemnation of atheistic and deistic views, was shared by the bourgeois editors and authors of press articles, none of whom undermined the significance of Christian religion in the social life. According to Tobias Bauch, editor of the periodical Patryota Polski, only a Christian could be a patriot and serve his fatherland well. ${ }^{96}$ This did not imply consent to a dominant position of the Catholic religion. Monitor authors promoted the Enlightenment idea of tolerance. Mitzler de Kolof argued, with complete confidence, that Protestants were equally good Commonwealth citizens as Catholics. ${ }^{97}$

trained to be able to render services to the home-country", Kamieński, Edukacya obywatelska, 30 .

${ }_{93}$ Ibid., 24.

${ }^{94}$ The author has clearly stated: "To mutually equalise the condition of the citizens is what I am willing not to do; the only thing I seek and solicit is respect for citizens of all the estates", ibid., 99.

${ }^{95}$ Butterwick-Pawlikowski, 'Chrześcijanin i obywatel', 175-6.

${ }^{96}$ Patryota Polski, Kartki Tygodniowe Zawierajacy (5 Feb. 1761), 2, 10-11.

${ }^{97}$ Mitzler de Kolof, Briefe eines Gelehrten aus Wilna, 36. 


\section{$\mathrm{V}$ \\ THE CONCEPT OF 'CITIZEN' AND THE STRUGGLE FOR THE RIGHTS OF THE BURGHER ESTATE}

In analysing the meaning of the concept of 'citizen' in the early modern Poland-Lithuania's political discourse, the arguments and concepts to which referred the noble and bourgeoisie parties to the conflict taking place in the Protestant circles in the late 1770s and early 1780 s, should be taken into account. In 1768, under a Polish-Russian treaty, the dissidents obtained rights equal to those of the Catholics. In the opinion of Protestant noblemen, the treaty's provisions only applied to the privileged estate, and only its members gained the status of equal citizens of the Commonwealth. ${ }^{98}$ Based on such an interpretation of the treaty, the nobility strove to maintain the social status quo which was in force in the Protestant Churches and opposed members of urban congregations being allowed to speak. The dissent was about such affairs as a further solicitation of Russian protection, financials, and the relationship between the two Protestant confessions (i.e. Lutheran and Reformed Protestantism). ${ }^{99}$

The position of the Protestant noblemen was manifested the most clearly in Christian Gottlieb Friese's treatise Uwiadomienie Bezstronne Publicznemi Dowodami Wsparte ... [A Neutral Announcement Based on Public Evidence...], which was published, in a Polish and German-language version, in $1783 .{ }^{100}$ Referring to the Cardinal Laws binding

98 The Protestants' strivings for regaining the political rights in the context of their struggle for the right of citizenship in the Commonwealth were described by Józef Wybicki and Adam Moszczyński in their memoirs. According to their concordant opinion, the dissidents wanted to be equal citizens and Poles in the country. See Józef Wybicki, Życie moje oraz wspomnienie o Andrzeju i Konstancji Zamoyskich, ed. by Stanisław Sierpowski (Kraków, 1927), 27; Adam Moszczeński, Pamiętnik do historii polskiej w ostatnich latach panowania Augusta III i pierwszych Stanistawa Augusta, ed. by Jan Konstanty Żupański (Poznań, 1858), 85.

${ }^{99}$ For a broader discussion, see Wojciech Kriegseisen, 'Ewangelicy wobec powstania kościuszkowskiego’, in Jerzy Kowecki (ed.), Kościuszko - powstanie 1794 r. tradycja. Materiały z sesji naukowej w 200-lecie powstania kościuszkowskiego 15-16 kwietnia 1994 r. (Warszawa, 1997), 91-122; Marta Kuc-Czerep, Niemieckojęzyczni mieszkańcy osiemnastowiecznej Warszawy [forthcoming, 2021].

100 Christian Gottlieb Friese, Uwiadomienie Bezstronne Publicznemi Dowodami Wsparte, O Sporach, Ktore trwaty ad 4 Junii a. c. między niektoremi Zgromadzeniami Augszpurgskiey nieodmienney Konfessyi, tak $w$ Krolestwie Polskim, jako też $w$ Wielkim Xięstwie Litewskim (Warszawa, 1783). 
in Poland-Lithuania and the provisions of the 1768 and 1775 treaties, the Protestant nobles maintained that the townsfolk and peasantry were a subservient class, unauthorised to participate in holding state or ecclesiastical offices and law-making. ${ }^{101}$ This was reflected in the terms used in this context: the word Bürger was applied to describe burghers (for instance, 'assembly of dissident burghers' was translated as 'dissidentischen Bürger Gemeinden'). ${ }^{102}$ Disobedient subjects (die Unterthanen), i.e. the townspeople, were unambiguously opposed to the obedient and modest citizens (Bürger). ${ }^{103}$ In this case, the German term was used to denote a citizen of the Commonwealth, which means that it functioned within one text in two meanings - as a burgher and citizen of the state. However, the Protestant nobles used the term 'citizen' solely to refer to the members of their own estate. ${ }^{104}$ Only August Stanisław Goltz, the primary opponent of emancipative strivings of the townsfolk, was regarded as a worthy citizen and respectable patriot. ${ }^{105}$

The burgher authors presented their arguments in several treatises and memorials which were produced at the Michał Gröll printery. ${ }^{106}$ Their authors justified the bourgeois postulates by referring to concrete concepts. Defining themselves as the 'third estate' within the Lutheran community, they demanded that the townsfolk be equalled in rights with the noble and clerical estate, which would translate into the right to hold Church offices and equal right to vote at synod sessions. ${ }^{107}$

${ }^{101}$ As the author overtly declared, "These same Dissident Burghers and peasants [German, Bürger und Bauern], as well as the very same Burghers and peasants of the reigning Religion have no vocem activum, nor can they be the Corpus representativum, and therefore they ... remain under the Direction and supervision of the Knighthood": ibid., 72 .

102 Ibid., 5.

${ }^{103}$ Elsewhere, 'worthy citizens' and 'loyal subjects' ("rechtschaffene Mitbürger und treue Unterthanen") are juxtaposed; ibid., 12-13, 164.

104 The phrase "We, the hereat-gathered citizens of the D[uch]-y of Masovia ..." opened the minutes of the meeting of the Warsaw Provincial Synod of 1782; ibid., 156.

${ }^{105}$ Let us point out that in this particular case, the word obywatel was not translated into German; ibid., 64.

${ }^{106}$ For a broader discussion, see Hanna Mieczkowska, ““... nakładem lub czcionkami Michała Grela...” Druki ewangelickie za zbioru Biblioteki Uniwersyteckiej w Warszawie', in Ewangelicy w dziejach, 69-92.

107 This was one of the arguments put forth by exponents of the Warsaw Lutheran congregation at the synod of Leszno in 1775. Gottfried Smend (ed.), 'Die Synoden der Kirche Augsburgischer Konfession in Großpolen im 16., 17. und 
In justifying their rights, the burghers referred to the sixteenth-century organisational practice of the Protestant Churches in Poland-Lithuania, with representatives of the three estates - nobility, clergy, and townsfolk participating in synod deliberations. They moreover referred to the fact that Protestant burghers and peasants outnumbered the noblemen of the same denomination. Yet, the key argument was finance. The burghers reminded that it was them who had mainly founded the churches, hospitals and schools which functioned in Poland-Lithuania. For this reason, full right was vested in them to co-decide on specific issues related to the functioning of the Protestant Churches. ${ }^{108}$

Above all, however, in giving grounds for their postulates, the burgher authors referred to the concept of 'citizen'/Bürger, interpreting it as extending to all the residents of the country. On equal terms with the nobility, the townspeople considered themselves citizens of the Commonwealth - as is attested by a manifesto of the bourgeois members of the Leszno synod from 1782, containing the phrase: "When the townsmen, as citizens of the Polish country ...". ${ }^{109}$ The aspirations of this estate were formulated the most expressly by the congregation's elder Abraham Emanuel Wolff; in his words, "Is not the Townsmen the Estate that provides the Homeland with learned people, and the Craftsmen \& Manufacturers with inventive and other ones? Is not a Burgher a no-less-loyal Citizen than a Nobleman? And, who cultivates the land, through which the Noble estate acquires the largest portion of its riches? Are they not a Burgher \& a Villager? Is it not so that it is the burgher \& the villager who, the most of all, offer their dearest Jewels for the Defence of the Homeland, in their own Children? Who keeps the Commerce running? Who is there to carry the Homeland's heaviest burdens?". ${ }^{110}$ It has to be stressed that

18. Jahrhundert', Jahrbuch des Theologischen Seminars der Unierten Evangelischen Kirche in Polen, ii (1930), 309.

${ }^{108}$ Krotkie na Pismie S. i rozumie gruntuiace sie Uwagi, nad powszechnym prawem Koscielnym $w$ Węgrowie ułożonym dla Evanielików Oboyga Wyznań $w$ Polszcze $i$ Litwie znayduiących się. Roku 1782 (Warszawa, 1783); List starszych i reprezentantów zboru warszawskiego, Biblioteka Uniwersytecka w Warszawie, Synod Ewangelicko-Reformowany (hereinafter: BUW, SER), 679, I, 138.

${ }^{109}$ BUW, SER, 641, 215v.

110 Abraham Emanuel Wolff, Usprawiedliwienie Medyka Generalnego Woysk Nayjaśniejszego Krola Imći Polskiego y Nayjaśnieyszey Rzeczypospolitey A. E. Wolffa, względem dwuletniey Administracyi uzbieranych za Granica pieniędzy dla Zborow Ewangielickich Reformowanych w Wielkiey Polszcze (s.l., 1778), 12. 
by 'citizen of the Commonwealth' this author understood not only the nobility but also burghers and peasants. The author of the anonymous letter published by Michał Gröll in 1788, entitled Usprawiedliwienie dysydentów Mieszczan i rolników ... na sejm roku 1788 ... podane [Excuse given for the dissident Burghers and cultivators ... submitted at the Sejm of the year 1788], expressed himself in a similar spirit. ${ }^{111}$ Many other examples of memorials, accounts and orations published by Gröll, with references to the 'citizen' in a similar understanding, could be quoted. ${ }^{112}$ Let us stress that the polemical writings printed on the initiative of Protestant burghers portray this group as regarding themselves as free inhabitants and citizens of Poland-Lithuania, observing the laws in force in its territory and, primarily, remaining loyal to its monarch, Stanislaus Augustus. ${ }^{113}$

There is no doubt that the dispute between the noblemen and burghers within the Protestant milieu and the polemics around it contributed to the formation of an ideology of the townspeople in the early period of the Four Years' Sejm sessions. ${ }^{114}$ This is evidenced by the scope of concepts and arguments applied in the bourgeois memorials

111 An anonymous letter of 1788 contains the following sentence: "The free common-folk of the townsmen rank and the agricultural Protestant one ... were seating in the states of the Most Serene Commonwealth under the Cardinal Law of the year 1768, being regarded in their townsmen and agricultural rank as current citizens of this country ...", Usprawiedliwienie dysydentów Mieszczan i rolników ... na sejm roku 1788 ... podane, in Janusz Woliński, Jerzy Michalski, and Emanuel Rostworowski (eds), Materiaty do dziejów Sejmu Czteroletniego (hereinafter: MDSC), ii (Wrocław, 1959), 68.

112 As an example, the oration by Pastor Aleksander Głowacki (published in print) contained the following statement: "Having liberty in Religion, we do enjoy genuine civil felicity in this country, whose Citizens we are. The wealth, fame, and life of ours have been ensured to us. We are not rightful in fearing a persecution, and can all, according to our estate and vocation, fulfil the obligations of a good Citizen and be useful to the Homeland", Aleksander Głowacki, Mowa Do Ludu Chrzescianskiego Augspurskiey Konfessyi: Przy Zakładaniu Kamienia pod Ottarz Nowego Koscioła W Lublinie Dnia 1. Października Roku 1787 Miana (Warszawa, 1788), 9.

113 Attaching a greater importance to the royal power than to the legislative prerogatives of the nobility first appeared in the dissident commentaries in the seventeenth century: Uwagi nad okolicznościami Dysydentów y wiadomość o co chodzi umysłom rozróżnionym między dysydentami Małopolskimi y Wielkopolskimi, BUW, SER, 641, 339; Augustyniak, 'Wpływ konfesjonalizacji', 77-8.

114 Such a view was expressed by Władysław Konopczyński, who postulated in-depth exploration of the issue; see Władysław Konopczyński, Polscy pisarze, 413. 
whose authors were Warsaw-based lawyers Michał Świniarski, Adam Mędrzecki, and Franciszek Barss. ${ }^{115}$ Direct contacts between the burgher Protestants, on the one hand, and the Lord Mayor (prezydent) Jan Dekert and his associates, on the other, definitely played an important part as well. ${ }^{116}$

It is worth to bear in mind that the term 'citizen' [obywatel] appeared in bourgeois journalistic texts. In 1789, Adam Mędrzecki had his pamphlet on Polish towns' rights with respect to the "governmental power, the executive, and the judiciary" published in print. ${ }^{117}$ Giving the justification of the claims proposed by urban dwellers, he referred to the order established the moment the Polish nation came into existence. In his view, every social estate received a specified task: the clergy was to serve the altar; the knighthood was meant to defend the homeland; the townsfolk were tasked with introducing industry in the country, thereby enriching the whole nation. According to this order, members of all three estates were to be "genuine, free citizens of this Country". 118

From the standpoint of the issue under analysis, it was important that the memorials written by burghers were also printed in a German translation. ${ }^{119}$ The printer Michał Gröll was very dynamic in this respect; thanks to his efforts, the second and third version of the 1789 'Memorial of Towns' was published in this language. ${ }^{120}$ His text included enunciations referring to love of the home country (Liebe zum Vaterlande), common good, and one's usefulness for the good of the common homeland; ${ }^{121}$ the rights of man and citizen (alle Rechte des Menschen und Bürger) were referred to as well. ${ }^{122}$ The townsmen's

115 For a broader discussion, see Krystyna Zienkowska, Stawetni $i$ urodzeni: ruch polityczny mieszczaństwa $w$ dobie Sejmu Czteroletniego (Warszawa, 1976), 74

116 See Krystyna Zienkowska, Jan Dekert (Warszawa, 1982), 190.

117 Adam Mędrzecki, Prawa miast polskich do wtadzy rządowey, wykonawającey $i$ sądowniczey (Warszawa, 1789).

118 Ibid., 4.

119 Władysław Smoleński, Jan Dekert: prezydent Starej Warszawy $i$ sprawa miejska podczas Sejmu Wielkiego (Warszawa, 1912), 44.

120 '[Memoriał Miast] [2nd and 3rd ed.] [1-7 Dec. 1789], in MDSC, ii, 339-57; Allerdurchlauchtigster König, Allergnädigster Herr! Und Allerdurchlauchtigste Konföderirte Stände der Republik!: [Inc.:] Da die ganze Nazion davon erschallete, wie patriotisch die Gesinnungen des gegenwärtigen Reichstages zu Rettung des Vaterlandes wären (Warschau, 1789).

121 "Er will seinem seinem Vaterlande nützlich sein", ibid., 3.

122 Ibid., 4. 
estate was rendered as der Bürger-Stand, als Bürger freier Städte. The nobility is regarded as the crown and ornament of the Polish nation; the virtues and fortitude of this estate are described as a model to follow (Staats-Bürger is the phrase used in this context). The townsmen, "all the inhabitants of this free land" (alle Einwohner dieses freien Landes), pointed to the need to cooperate and maintain the nation's unity, under threat of foreign intervention. ${ }^{123}$ They resorted to the authority of the king, who in the German version is named als Staats-Bürger; ${ }^{124}$ the ruler is shown as the father of a free people (Vater eines freien Volks). ${ }^{125}$

Worthy of note are the views regarding the 'town question' voiced by Johann Ferdinand Nax, architect and economic writer, who was born into a Lutheran bourgeois family residing in Gdansk. ${ }^{126}$ In 1789 , he published an economic treatise which polemicised against a book by Stanisław Staszic; ${ }^{127}$ in his next publication, of 1790, Nax addressed a number of problems in the economics of the state. ${ }^{128}$ His views concerning economic and social questions were in a number of points convergent with the stance of Wawrzyniec Mitzler de Kolof, editor of the Monitor. This is true for the interpretation of the idea of 'citizen'. In the introduction to the book Uwagi nad uwagami [Remarks to Remarks], regarding himself as a citizen of Poland-Lithuania, Nax justified his duty to participate in the debate on the state reform. ${ }^{129}$ Further on, he presents his own opinion on the social relations in the Commonwealth. As he observed, a situation where access to dignities and offices was determined not by one's talent or virtue but rather by a noble family background, did not contribute to the commonweal. ${ }^{130}$

123 '[Memoriał Miast]', 343.

${ }^{124}$ Allerdurchlauchtigster König, Allergnädigster Herr!, 4.

125 Ibid., 5.

${ }^{126}$ Rabowicz, 'Jan Ferdynand Nax', xxii.

127 Johann Ferdinand Nax, Uwagi nad uwagami, czyli obserwacje nad książa, która $w$ roku 1785 wyszła pod tytutem Uwagi nad życiem Jana Zamoyskiego, kanclerza $i$ hetmana w. kor. (Warszawa, 1789). For a broader discussion, see Konopczyński, Polscy pisarze, 271-2; Anna Grześkowiak-Krwawicz, 'Publicystyczna dyskusja wokół "Uwag nad życiem Jana Zamoyskiego" Stanisława Staszica', Napis. Pismo poświęcone literaturze okolicznościowej $i$ użytkowej, v (1999), 132-4.

${ }^{128}$ Johann Fedrinand Nax, Wyktad poczatkowych prawidet ekonomiki politycznej $z$ przystosowaniem przepisów gospodarstwa narodowego do onego wydźwignienia i polepszenia, stosownie do aktualnego stanu, w którym rzeczy zostają (Warszawa, 1790).

${ }^{129}$ Nax, Uwagi nad uwagami, 440.

${ }^{130}$ Ibid., 376. 
As it clearly stems from his arguments, Nax regarded every single dweller to be a Commonwealth citizen, regardless of their estate background. Hence, every nobleman, burgher, and farmer, ${ }^{131}$ and every clergyman too, was a citizen. ${ }^{132}$

Nax opted for admitting town deputations to participate in diet sessions; he considered wrongful the deprivation of this right, which would otherwise belong to every citizen, from the townspeople. Fulfilment of this particular postulate was, to his mind, of the essence to the commonweal. However, Nax was aware of the difficulties related to the implementation of these solutions. On the one hand, representatives of municipalities, once made part of the diet, would quickly become dominated by the noblemen's majority; on the other, town dwellers were not educated well enough to form a parliamentary house dedicated to the townspeople. ${ }^{133}$

During the Kościuszko Insurrection, the term 'citizen' appeared with extremely high frequency in journalistic texts, and in the appeals or decrees of the insurgent authorities. ${ }^{134}$ It was a period of the intensified political activity of townsmen, who got actively involved in the uprising actions. The Insurrection reinforced and deepened the ideological changes in the awareness of the bourgeoisie, who became active in politics. ${ }^{135}$ Also, the Protestant burghers of Warsaw became actively involved in these developments (given the reluctant position of the Protestant nobles). Many of them signed their accession to the uprising and partook in the organisation of its authorities. According to Wojciech Kriegseisen, this came as a final result of the long years of struggle for the emancipation of the bourgeois majority from the influence of the narrow elite consisting of noble officials and associated with the royal

${ }^{131}$ Of the inhabitants of rural areas, Nax wrote: "the Citizen being the most beneficial to the Country, namely, the tiller", ibid., 30.

132 "The Commonwealth is much concerned about every Priest being a Citizen, and that the he [= they] prefer the obligations he owes to the Homeland above all the subsequent duties of his estate", ibid., 46.

${ }^{133}$ Ibid., 98.

134 Gazeta Wolna Warszawska published numerous proclamations and advertisements, among them 'Citizen Wybicki's proclamation to the "citizens" of several voivodeships': 'Odezwa ob. Wybickiego Pełnomocnika, do obywatelów Województw Rawskiego, Kujawskiego, Łączyckiego i Sieradzkiego', Gazeta Wolna Warszawska, 43 (Sept. 1794).

${ }^{135}$ See, in broader context: Bogusław Leśnodorski, Polscy Jakobini. Karta z dziejów insurekcji 1794 roku (Warszawa, 1960). 
court and Russian legation in Warsaw. ${ }^{136}$ The initiative of Michał Gröll, who in 1794 launched in Warsaw an informal German-language official insurgent newspaper Warschauer Zeitung Für Polens Bürger, is worthy of attention in this context. ${ }^{137}$ It published instructions or orders of the insurgent authorities and information regarding the actions carried out by the insurgent army. The periodical's language layer is remarkable as it repeatedly referred to the French Revolution terms. ${ }^{138}$ The concept of Bürger, appearing in the paper's title, ought to be analysed in this sense; rather than a burgher, it evidently denoted a citizen of the state, understood in a modern sense. ${ }^{139}$ This is how a declaration made by Michał Gröll should be interpreted: involved for years in the struggle for political rights for burghers, he signed the title page of his periodical thus: Gedrukt bey Bürger Michael Gröll, $1794 .{ }^{140}$

\section{VI \\ CONCLUSIONS}

The above analysis certainly does not exhaust all the issues related to the position and significance of the word 'citizen' [obywatel] in the political discourse of the early modern Polish-Lithuanian Commonwealth. However, certain conclusions can already be drawn: the durability of the functioning of the concept, in terms of a participant of the country's political life, is to be emphasised. It was an important element of the nobility's dominant ideology. As remarked by Reinhart Koselleck, it was rooted in the European tradition of Latin, with civis denoting a power-wielding person. In this meaning, in line with the estate-of-the-realm social system, free peasants, citizens of towns, noblemen and magnates had always been cives of some societas civilis. ${ }^{141}$

${ }^{136}$ Kriegseisen, 'Ewangelicy wobec powstania', 111.

${ }^{137}$ For more on this magazine, see Karol Drewnowski, 'Dziennikarstwo polskie za czasów Powstania Kościuszkowskiego', Przeglad Historyczny, xxxiii, 1 (1936), 238-45; Andrzej Woltanowski, Prasa i pisma periodyczne powstania kościuszkowskiego (Białystok, 1984), 270-87.

${ }^{138}$ Kriegseisen, 'Ewangelicy wobec powstania', 111.

${ }^{139}$ Reinhart Koselleck remarks that the term was coined in the revolutionary France.

${ }^{140}$ Warschauer Zeitung Für Polens Bürger, 1 (1794).

${ }^{141}$ Koselleck, Spree, and Steinmetz, 'Drei bürgerliche Welten?', 16. 
Stanisław Staszic and Hugo Kołłątaj, the major political writers of Polish Enlightenment, referred to this tradition, whilst even more radical views were advocated by Franciszek Salezy Jezierski.

Worthy of attention, therefore, is the interpretation of the concept of 'citizen' proposed by German-speaking townsmen active in Warsaw in the latter half of the eighteenth century. While they referred to the ancient tradition to a lesser extent, they mostly tended to draw upon the resource of Polish Enlightenment thought. Through their activities as book traders and printers, both Wawrzyniec Mitzler de Kolof and Michał Gröll launched works of the period's leading philosophers into the Warsaw market. Their initiatives in the press market influenced public opinion in the spirit of the ideas of the enlightened bourgeoisie.

It has to be stressed that the bourgeois definition of the concept of 'citizen' was proposed in Monitor already in the 1770s, long before the Four Years' Sejm was launched. It referred to the understanding of the term as inhabitant [mieszkaniec, domownik], as present in the Polish language of the time. This led to the extension of the concept to all the inhabitants of Poland-Lithuania, the nobility, burghers, and peasants. In the socio-political realities of the Commonwealth in the period concerned, the proposition was a daring one. It definitely impacted the socio-political awareness of the bourgeoisie and set the level of its political aspirations. For this reason, regarding those burghers as the promoters of a modern conception of citizenship would not be much of an exaggeration.

transl. Tristan Korecki

\section{SELECTED BIBLIOGRAPHY}

Bardach Juliusz, 'Czy istniało obywatelstwo w szlacheckiej Rzeczypospolitej? W związku z pracą S. Grodziskiego, Obywatelstwo w szlacheckiej Rzeczypospolitej', Czasopismo Prawno-Historyczne, xvii, 2 (1965), 261-6.

Butterwick-Pawlikowski Richard, 'Chrześcijanin i obywatel w dyskursie politycznym drugiej połowy XVIII wieku', in Anna Grześkowiak-Krwawicz and Jerzy Axer (eds), Wartości polityczne Rzeczypospolitej Obojga Narodów. Struktury aksjologiczne i granice cywilizacyjne (Warszawa, 2017), 175-95.

Friedrich Karin, 'Obywatele i obywatelskość w wielonarodowej Rzeczypospolitej', in Anna Grześkowiak-Krwawicz and Jerzy Axer (eds), Wartości polityczne Rzeczypospolitej Obojga Narodów. Struktury aksjologiczne i granice cywilizacyjne (Warszawa, 2017), 119-50.

Grodziski Stanisław, Obywatelstwo w szlacheckiej Rzeczypospolitej (Kraków, 1963). 
Grześkowiak-Krwawicz Anna, 'Czy historyk powinien interesować się językiem?’, in Aleksandra Antoniewicz, Rozalia Kosińska, and Piotr Skowroński (eds), Zmierzch $i$ świt. Stanistaw August $i$ Rzeczpospolita 1764-1795 (Warszawa, 2015), 31-40.

Grześkowiak-Krwawicz Anna, Dyskurs polityczny Rzeczypospolitej Obojga Narodów (Toruń, 2018).

Kriegseisen Wojciech, 'Ewangelicy wobec powstania kościuszkowskiego', in Jerzy Kowecki (ed.), Kościuszko - powstanie 1794 r. - tradycja. Materiaty z sesji naukowej w 200-lecie powstania kościuszkowskiego 15-16 kwietnia 1994 r. (Warszawa, 1997), 91-122.

Konopczyński Władysław, Polscy pisarze polityczni XVIII wieku (Kraków, 2012).

Koselleck Reinhart, Kritik und Krise: Eine Studie zur Pathogenese der bürgerlichen Welt (München, 1959).

Koselleck Reinhart (ed.), Historische Semantik und Begriffsgeschichte (Stuttgart, 1979).

Marta Kuc-Czerep - early modern history, 16th-18th cc. urban history; assistant professor at the Department of Early Modern History, Institute of History, Polish Academy of Sciences; e-mail: m_kuc@tlen.pl 